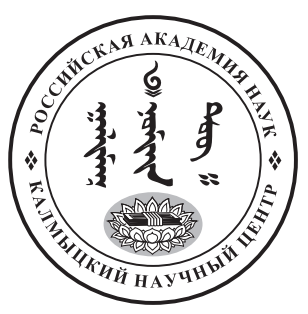

Published in the Russian Federation

Oriental Studies (Previous Name: Bulletin of the Kalmyk Institute

for Humanities of the Russian Academy of Sciences)

Has been issued as a journal since 2008

ISSN: 2619-0990; E-ISSN: 2619-1008

Vol. 14, Is. 5, pp. 910-918, 2021

Journal homepage: https://kigiran.elpub.ru

УДК / UDC 94(47).065

DOI: 10.22162/2619-0990-2021-57-5-910-918

\title{
В. Н. Татищев и вопросы улучшения экономического положения калмыцкого народа
}

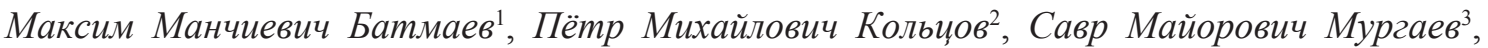
Семён Александрович Умгаев

${ }^{1}$ Калмыцкий государственный университет им. Б. Б. Городовикова (д. 11, ул. Пушкина, 358000 Элиста, Российская Федерация)

доктор исторических наук, профессор

iD) 0000-0002-2233-0647. E-mail: history@kalmsu.ru

${ }^{2}$ Калмыцкий государственный университет им. Б. Б. Городовикова (д. 11, ул. Пушкина, 358000

Элиста, Российская Федерация)

доктор исторических наук, профессор, заведующий кафедрой

(iD) 0000-0001-9776-3650. E-mail: petrkoltsov52@mail.ru

${ }^{3}$ Калмыцкий государственный университет им. Б. Б. Городовикова (д. 11, ул. Пушкина, 358000 Элиста, Российская Федерация)

кандидат исторических наук, доцент

iD 0000-0001-9021-2872. E-mail: murgaev_sm@mail.ru

${ }^{4}$ Калмыцкий государственный университет им. Б. Б. Городовикова (д. 11, ул. Пушкина, 358000

Элиста, Российская Федерация)

старший преподаватель

(iD) 0000-0003-0778-1607. E-mail: sam_umg@yahoo.com

(C) КалмНЦ РАН, 2021

(C) Батмаев М. М., Кольцов П. М., Мургаев С. М., Умгаев С. А., 2021

Аннотация. Введение. Данная статья посвящена государственно-политической деятельности Василия Никитича Татищева, который с 1741 по 1745 гг. служил Астраханским губернатором и по долгу службы занимался делами калмыцких степей. Цели и задачи. В статье рассматривается поднятый самим В. Н. Татищевым вопрос об обеднении широких масс калмыков, которые порой теряли последний скот, в том числе и лошадей. Этот вопрос волновал губернатора из политических соображений - он считал, что без коней калмыки для Российской Империи бесполезны. Материалы и методы. Статья основана на архивных материалах, в ней приводится основная историография, использованная авторами для комплексного понимания личности В. Н. Татищева. Результаты. Социально-экономические вопросы В. Н. Татищев поднимал неоднократно и в официальном общении с калмыцким наместником Дондук-Даши, и в частных беседах. Он высказывал различные идеи о причинах обеднения калмыков, об отличии калмыцких кочевий в 40-х гг. XVIII в. от времён Аюки-хана, а также разбирался в вопросах калмыцкого рыболовства и отходничества, попытавшись добиться улучшения положения «бесскотных» 
калмыков. Предложения В. Н. Татищева по улучшению социально-экономической ситуации, видимо, не достигли желаемого результата. Вероятной причиной неудачи было как сопротивление калмыцких владетелей и зайсангов, так и общее несовершенство управления степными делами. Bblвoдbl. В статье рассматриваются важные практические вопросы регионального управления в Российской Империи. В. Н. Татищев был типичным управленцем, вышедшим из петровского времени. Он был верным сыном России, но при этом обладал практичным и пытливым умом, совмещая вопросы государственного управления и занятия наукой.

Ключевые слова: В. Н. Татищев, калмыки, Дондук-Даши, имперская политика, социальноэкономическое положение, рыболовство на Волге, калмыцкое отходничество

Для цитирования: Батмаев М. М., Кольцов П. М., Мургаев С. М., Умгаев С. А. В. Н. Татищев и вопросы улучшения экономического положения калмыцкого народа // Oriental Studies. 2021. T. 14 (5). C. 910-918. DOI: 10.22162/2619-0990-2021-57-5-910-918

\title{
Vasily Tatishchev and Issues of Improving the Kalmyk People's Economic Conditions
}

\author{
Maksim M. Batmaev', Pyotr M. Koltsov², Savr M. Murgaev ${ }^{3}$, Semyon A. Umgaev ${ }^{4}$ \\ ${ }^{1}$ Gorodovikov Kalmyk State University (11, Pushkin St., 358000 Elista, Russian Federation) \\ Dr. Sc. (History), Professor \\ (iD)0000-0002-2233-0647. E-mail: history@kalmsu.ru \\ ${ }^{2}$ Gorodovikov Kalmyk State University (11, Pushkin St., 358000 Elista, Russian Federation) \\ Dr. Sc. (History), Professor, Head of General History Department \\ (iD) 0000-0001-9776-3650.E-mail: petrkoltsov52@mail.ru \\ ${ }^{3}$ Gorodovikov Kalmyk State University (11, Pushkin St., 358000 Elista, Russian Federation) \\ Cand. Sc. (History), Associate Professor \\ (iD)0000-0001-9021-2872. E-mail: murgaev_sm@mail.ru \\ ${ }^{4}$ Gorodovikov Kalmyk State University (11, Pushkin St., 358000 Elista, Russian Federation) \\ Senior Lecturer
}

(iD 0000-0003-0778-1607.E-mail: sam_umg@yahoo.com

(c) KalmSC RAS, 2021

(C) Batmaev M. M., Koltsov P. M., Murgaev S. M., Umgaev S. A., 2021

\begin{abstract}
Introduction. This article is devoted to the activities of Vasily Nikitich Tatishchev, when Astrakhan governor (1741-1745) responsible for the affairs of the Kalmyk steppes. It is aimed to examine his projects designed to amend the impoverishment of the broad masses of Kalmyks often left without their livestock, even without horses. The question was raised by Tatishchev himself; the governor was worried about its political implications because Kalmyks without horses were of no use for the Russian Empire. Materials and methods. The article is based on archival materials, as well as the historiography that sheds light on Tatishchev as the statesman and politician. Results. The governor repeatedly discussed the issues of the worsened social-economic situation of the people with the Kalmyk namestnik (leader) Donduk Dashi, both on official occasions and in private communication. He had various explanations for their economical degradation, pointing out the difference in the nomads' situation of the 1840s as compared with that in Khan Ayuka's time. His involvement in the issues concerning fishing and seasonal work of the impoverished Kalmyks shows that the governor seemed to be interested in helping them, but his projects to improve the Kalmyks' socio-economic situation were largely unsuccessful. The reasons for the failure may be found both in the resistance of the Kalmyk rulers and zaisangs and the general weaknesses of the administration when dealing with the steppe affairs.

Keywords: Tatishchev, Kalmyks, Donduk Dashi, imperial policy, socio-economic situation, fishing on the Volga, Kalmyk seasonal works

For citation: Batmaev M. M., Koltsov P. M., Murgaev S. M., Umgaev S. A. Vasily Tatishchev and Issues of Improving the Kalmyk People's Economic Conditions. Oriental Studies. 2021. Vol. 14 (5): 910-918. (In Russ.). DOI: 10.22162/2619-0990-2021-57-5-910-918
\end{abstract}




\section{Введение}

Василий Никитич Татищев оставил великолепный и блистательный след в российской истории не только как учёный и автор «Истории Российской», но и как верный сын Отечества, офицер, чиновник и управитель. С калмыцкой степью его связывает пребывание на посту Астраханского губернатора.

В. Н. Татищев был выдающимся государственным деятелем, много лет служил в армии, принимал участие в сражениях Северной войны. В послужном списке В. Н. Татищева значатся такие значимые должности: советник Берг-коллегии, управитель уральских и сибирских заводов, начальник Башкирского края и Оренбургской экспедиции, астраханский губернатор и, одновременно, управитель Калмыцкой экспедиции. Он руководил монетным делом, по поручению Петра I выезжал в Швецию для изучения экономики и финансов.

В лице В. Н. Татищева петровская Россия имела целеустремленного государственного деятеля, тонкого дипломата, энергичного администратора. После смерти Петра I, особенно в годы бироновщины, В. Н. Татищев сохранил верность своим убеждениям, не принял антинационального режима и был отстранен от должности астраханского губернатора. Находясь в опале, В. Н. Татищев установил связи с заговорщиками во главе с А. П. Волынским и едва не погиб вместе с ними. Его спасли смерть императрицы Анны Иоанновны и падение Бирона.

Политическая деятельность В. Н. Татищева составляла лишь одну из сторон его жизни, другой же, не менее важной и успешной, было служение науке. В нем органично сочетались политик и ученый широкого кругозора, много сделавший в географии, истории, философии, экономике и горном деле. В своих трудах В. Н. Татищев наибольшее внимание уделял социологии и политике, подчиняя их задачам обоснования программы петровского государства.

В верности, талантах и энергии Василия Никитича не приходится сомневаться. Без сомнения, эти качества разглядели в нём и современники: В. Н. Татищев занимался важными вопросами регионального соци- ально-экономического и политического развития и при Петре, и при Елизавете Петровне, и даже при Анне Иоановне.

\section{Материалы и методы}

Настоящая статья основана на материалах Российского государственного архива древних актов (далее - РГАДА), а также на материалах Национального архива Республики Калмыкия (далее - НА РК). Основой для рассмотрения интенций и намерений В. Н. Татищева стала историография, позволяющая составить цельный образ государственного деятеля, патриота и учёного. Коллектив автором последовательно рассмотрел инициативы В. Н. Татищева по улучшению социально-экономического положения, используя историко-генетический метод.

\section{История вопроса}

Естественно, масштаб личности, длительная служба на благо России, разносторонняя и разноплановая деятельность, неоднозначные инициативы - всё это нашло отражение в историографии. Биография В. Н. Татищева, его верная служба, его научная работа обусловили пристальный интерес к нему со стороны историков. Из самых интересных работ, посвящённых В. Н. Татищеву, можно выделить короткий и ёмкий разбор исторической и государственной деятельности В. Н. Татищева от Г. М. Дейча [Дейч 1962], а также замечательную биографию В. Н. Татищева, написанную А. Г. Кузьминым в серии «Жизнь замечательных людей» [Кузьмин 1987].

Фигура В. Н. Татищева вызывает интеpec, правда, в большей степени его научной деятельностью. Его «История Российская», первая ласточка, подверглась некоторой критике со стороны современников и последующих поколений историков, породив дискуссию об истории России ещё в XVII в. (см.: [Щербатов 1789; Щербатов 1792; Болтин 1789; Болтин 1794]). Если А. Л. Шлецер, укорив В. Н. Татищева в некотором непрофессионализме за незнание языков, всё же признал его работу полезной, то Н. М. Карамзин положил начало движению «скептиков», которые критиковали Василия Никитича [Качин 2014: 100-101]. Сейчас, раз- 
умеется, «История Российская» рассматривается больше как памятник исторической, научной и социально-политической мысли своего времени. Тем не менее в современный период заслуги В. Н. Татищева, одного из родоначальников российской исторической науки, не подлежат сомнению.

Не иссякает интерес к В. Н. Татищеву и в современной России: в 2009 г. была издана работа, сфокусированная на научном труде: «Василий Никитич Татищев - автор и редактор „Истории Российской“» [Свердлов 2009].

Однако, особенно в вопросах истории тех регионов, которых коснулась деятельность В. Н. Татищева, современные историки в статьях анализируют его деятельность именно как государственного администратора. Этот вопрос имеет как научную, так и общественную важность.

Так, 21 декабря 2001 г. в астраханской областной газете «Волга» было опубликовано интервью губернатора А. П. Гужвина, ныне, к сожалению, покойного. Корреспондент обратился к нему:

Анатолий Петрович ... в декабре 1741 года, 260 лет тому назад, на губернаторский пост в Астраханской губернии заступил Василий Никитич Татищев ... Какой видится вам по прошествии веков личность самого именитого вашего предшественника на столь ответственном посту?

- По тем книгам и материалам о Татищеве, которыми я располагаю, у меня создался образ выдающегося государственного деятеля России. Татищев был прекрасно образованный человек с большим государственным мышлением. Он был ... облечен высокими полномочиями. Фактически Татищев ... выполнял целый ряд имперских государственных функций ... Российская империя в то время являлась максимально централизованным государством, а Татищев имел достаточно хорошие возможности и реализовывал их, самое главное, с точки зрения объединения и укоренения народов, которые могли бы наполнять территорию Астраханской губернии жизнью и благоденствием [Интервью с губернатором... 2001].

О том, что имя и дела В. Н. Татищева не забываются, в том числе и в Астрахани, говорит тот факт, что 14-16 октября 2004 г. состоялась Международная научная кон- ференция «Исторические судьбы России в научном наследии В. Н. Татищева», по материалам которой был издан сборник [Исторические судьбы России... 2004]. В последующие года проводились и другие конференции.

Деятельность В. Н. Татищева на посту астраханского губернатора

В. Н. Татищев, будучи астраханским губернатором, возглавлял также деятельность калмыцкой комиссии, особого административно-управленческого органа, который контролировал ситуацию в Калмыцком ханстве. Об отношениях В. Н. Татищева с правителями ханства сообщается, чаще всего попутно, в нескольких работах, из которых надо отметить две: Н. Попов «В. Н. Татищев и его время» [Попов 1861] и Н. Н. Пальмов «К астраханскому периоду жизни В. Н. Татищева» [Пальмов 1925]. Наконец, в упомянутых выше материалах Международной научной конференции опубликовано сообщение М. М. Батмаева «В. Н. Татищев как руководитель Калмыцких дел» [Батмаев 2004].

Итак, 21 марта 1741 г. скончался от давней болезни хан Дондук-Омбо, из-за чего в калмыцкой степи началась политическая борьба за освободившееся место калмыцкого правителя. Проблема состояла в том, что оставленный ханом наследник был малолетним (всего 10 лет), а жена его, Джан, была не из калмыцкого рода. Калмыцкие владетели и зайсанги не желали видеть над собой таких правителей, что заставило Джан стремиться принудить их к подчинению с помощью силовых методов. Желая «калмыцких владельцев перевесть», она вызывала среди калмыков сопротивление [РГАДА. Ф. 16. Д. 619. Л. 100].

При этом был и другой претендент на престол - сын самого хана Аюки Галдан Данжин. Симпатии большинства были на его стороне, тем более что методы Джан нельзя назвать гуманными: её люди отлавливали в степи выступающих против власти «ханши» владельцев и забивали до смерти или арестовывали. Кто-то был изгнан или ушёл сам. В конце концов, и Галдан Данжин был убит, после чего Дарма-Бала, его мать, попросила российские власти признать наследником Дондук-Даши, внука Аюки-хана [РГАДА. Ф. 16. Д. 619. Л. 100]. 
Российские власти согласовали кандидатуру Дондук-Даши в качестве «наместника», но направили с ним опытного и делового человека, который смог бы разобраться в калмыцких делах и управлять ими. Таким человеком стал В. Н. Татищев, который вскоре вступил в должность Астраханского губернатора.

Перед отъездом в калмыцкую степь В. Н. Татищева и Дондук-Даши власти соответствующим образом проинструктировали (например, ханшу Джан необходимо было либо изловить, либо выделить ей улус), разослали необходимые письма местным владельцам и т. д. Самого Дондук-Даши заставили дать реверс (клятву-присягу) и отдать сына в аманаты [НА РК. Ф. 36. Д. 135. Л. 5об.-7об.].

После урегулирования государственных дел, утверждения Дондук-Даши на ханство, В. Н. Татищев приступил к своим излюбленным занятиям историей, а также к калмыцким делам. Одним из направлений его деятельности на посту губернатора была инициативная попытка улучшить экономическое положение широких слоев калмыцкого населения. Такую задачу В. Н. Татищев поставил себе исходя из практических соображений. Верный принципу имперской политики России, он видел в калмыках важный противовес иноплеменным кочевникам и буфер от набегов других степняков. Однако экономическое положение калмыков было таким плачевным, что широкие слои населения не могли позволить себе иметь скот, в частности - лошадей. А без коней калмыков невозможно было использовать для имперских целей.

Уже через полтора месяца после прибытия в Астрахань он пишет вице-канцлеру А. И. Остерману, что из улусов Джан много продается из захваченных ею и другими владельцами пленных калмыков на Кубань и другие места, «чрез что весь калмыцкой народ вскоре исчезнуть может». По его мнению, надо запретить кубанцам, северокавказским народам, тогда не входившим в состав России, а также астраханским татарам покупать калмыков и строго за этим следить. Он предлагал разрешить русским покупать калмыков, но в здешних городах купленных не держать, «а выводить в Русь и отдавать комендантам, за которых из казны платить от 10 до 15 лет по 15 рублей, от
15 до 40 лет по 25 рублей, которых можно употребить в службу вместо рекрут, в чем немалая польза быть может» [НА РК. Ф. 36. Д. 133. Л. 25-26]. Концовка его предложения несколько непонятна: почему люди, купившие калмыков, особенно детей, должны их сразу продавать казне?

8 октября В. Н. Татищев обедал у генерал-поручика А. И. Тараканова, командующего Царицынской укрепленной линией, где был и царицынский комендант полковник П. Ф. Кольцов. В. Н. Татищев говорил, что для отражения и прекращения казахских набегов и для лучшего наблюдения за калмыками нужно на Яике, ниже Яицкого городка, к Индерским горам, в удобном месте построить город и населить его драгунами и казаками, о чем он уже представлял «в высочайший кабинет» [НА РК. Ф. 36. Д. 132. Л. 27]. По Волге от Царицына до Астрахани он предлагал построить шесть небольших городков и заселить их 2 тыс. казаков. Между казачьими городками, как считал В. Н. Татищев, будет достаточно для кочевий калмыков, а Ахтубу оставить свободной для них [НА РК. Ф. 36. Д. 132. Л. 27].

18 октября В. Н. Татищев из Черного Яра ездил на шлюпке через Волгу на калмыцкий базар, с ним был черноярский комендант подполковник В. Пилюгин ${ }^{1}$. Он рассказывал В. Н. Татищеву, что ежедневно на базар приезжают человек по сто калмыков и при них для контроля торговли не бывает ни владельца, ни зайсанга. Далее В. Пилюгин пояснил, что торг калмыкам здесь был запрещен, но вновь разрешен по просьбе черноярцев. По какой-то причине муку им не продавали, поэтому калмыкам приходилось покупать печеный хлеб и просяную крупу кулями.

В одной из бесед с наместником В. Н. Татищев говорил, что знает: «... хан Дондук-Омбо получаемую от всероссийского двора в жалованье муку отдавал калмыцкому народу за великую цену из росту (т. е. с процентами. - М. Б., П. К., С. М., C. У.), отчего калмыцкой народ пришел в наисвясчее разорение и скудость; тогда тем более непонятно, почему калмыкам не разрешали покупать муку у торговцев повольной ценою» [НА РК. Ф. 36. Д. 132. Л. 203].

1 Здесь и далее ряд имен приводится без отчества или инициалов в соответствии с источником. 
Дондук-Даши вслед за В. Н. Татищевым осудил действия Дондук-Омбо и заверил, что «...сам намерен столько о исправлении убогих прилежать, сколько его возможности будет» [НА РК. Ф. 36. Д. 132. Л. 203]. В декабре 1741 г. в разговоре с В. Н. Татищевым Дондук-Даши сказал, что во всех улусах запретил продавать малолетних калмычат, только имеется здесь, в Астрахани, у «татар и бухарцев в покупке оных немалое число», и чтобы В. Н. Татищев как губернатор приказал им впредь покупать запретить, а имеющихся ныне у них переписать [НА РК. Ф. 36. Д. 132. Л. 203, 217].

\section{Рыболовство}

K середине XVIII в. отношения калмыков с соседним российским населением обострились из-за вопроса о рыболовстве. В связи с частичным оседанием, обеднением по различным причинам, не в последнюю очередь из-за междоусобиц владельцев, все большее количество калмыцкого населения стало заниматься рыболовством, что привело к столкновениям с русским населением. В. Н. Татищев, став астраханским губернатором вплотную занялся этой сложной проблемой.

Вначале он напомнил А. И. Остерману: «...калмыки имеют жалованные грамоты и договоры утвержденные, что им по Волге везде рыбу ловить кроме что в близости учугов, но потом и оным воспресчать, грабить и бить их начали» [НА РК. Ф. 36. Д. 133. Л. 63].

15 января 1742 г. В. Н. Татищев уведомил наместника, что он с полковником В. П. Беклемишевым составили определение (по просьбе наместника), согласно которому «калмыцкому населению разрешается ловить рыбу по Волге, озерам и протокам без запрещения. Вместе с тем здешние купцы просят, что в летнее время калмыкам рыбу ловить везде оставляют свободно, только в беляшное время (когда рыба, особенно осетровые, идет к морю) два месяца, а именно октябрь и ноябрь, калмыкам в Волге от песчаного до учугов рыбу не ловить, а ловить в эти два месяца в малых протоках и озерах» [НА РК. Ф. 36. Д. 140. Л. 36]. Наместник на то согласился.

Кроме того, губернатор указывал наместнику: «...вы изволите объявлять, что калмыки изъубожели и без свободного в рыбной ловле допущения исправить и скот завести невозможно», «а без скота они во услуги ея императорского величества негодны, что сущая правда» [НА РК. Ф. 36. Д. 140. Л. 36]. Однако местные купцы, которые хорошо осведомлены о нынешнем состоянии калмыков, «представляют, что калмык ловлею рыбы нынешним порядком не поправить и скота не завести, потому что при ватагах калмыки хотя в год столько вырабатывают, чтоб всякий лошадь купить мог, только не купят затем, что владельцы, зайсанги и посланцы (посланные от владельцев по улусным делам люди. - $M$. Б., П. К., С. М., С. У.) их грабят немилостиво, а деньги, пришед, манжики выманивают» [НА РК. Ф. 36. Д. 140. Л. 36].

Далее В. Н. Татищев заметил, что на ватагах может найти работу 1,5-2 тысячи человек, и каждый может заработать столько, что за два года лошадь и прочую необходимую скотину может купить. Губернатор посоветовал наместнику, что «... на все ватаги определить добрых надзирателей и велеть от промышленников (т. е. от хозяев ватаг), деньги принимая, каждому работнику-калмыку только на крайнюю нужду выдавать, а что помимо этого соберется проследить, чтоб была на эти деньги куплена скотина... и так можете в краткое время со скотом сделать, а о грабеже и обманах запретить» [НА РК. Ф. 36. Д. 140. Л. 36]. Хотя наместник и согласился с этим предложением, однако время показало нереальность подобных советов.

Тем не менее на первых порах дело оживилось. 13 марта 1742 г. у В. Н. Татищева был зайсанг Сойбин Иши и представил ему посланных от наместника трех зайсангов, которые будут для разбора судных и спорных дел между калмыками и россиянами и для развода обнищавших на ватаги [НА РК. Ф. 36. Д. 142. Л. 75]. Необходимо отметить, что некоторые указы российского правительства в какой-то мере сдерживали порой инициативу губернатора в его попытках оздоровления внутренней жизни калмыцкого общества.

Так, например, в указе В. Н. Татищеву от 14 апреля 1741 г. говорилось: «Что принадлежит до калмыцких внутренних малых грабительств, оные вам так отвращать, чтоб из того в калмыцком народе нового смятения быть не могло, ибо ранее такие их 
малые ссоры разбирали их ханы по своим правилам. А если ныне вдруг при новом наместнике ту их вольность отнять, то и многие из калмыцкого народа видя, что от Дондук-Даши противу вольности их взят в аманаты сын, поопасуются того, чтоб со временем чрез него не похотели мы и всю их вольность отнять, и тако в том вам весьма искусным и склонным образом поступать и добрым способом отвращать, а на иное и сквозь перстов смотреть надлежит» [НА РК. Ф. 36. Д. 150. Л. 63].

В одном из своих писем Дондук-Даши писал В. Н. Татищеву, что с давних лет, еще когда калмыки и татары кочевали вместе, тогда в мочагах в урочище Караболе рыбу ловили неводами. Калмыкам разрешалось там ловить в определенных местах для пропитания, а лишнюю рыбу продавать только своим калмыкам. В города для продажи запрещалось возить.

Также Дондук-Даши напомнил, что калмыки ныне (в 1742 г.) впали в крайнюю нужду и если им запретить продавать рыбу в городах, то они не смогут обеспечить себя хлебом и одеждой, что повлечет за собой нехорошие последствия в виде продажи своих детей за границу или вынужденного разбоя. На предложение В. Н. Татищева, чтобы калмыки нанимались на работы в городах или в учугах и тем поправляли свое положение, наместник (Дондук-Даши) ответил, что скудных, проще говоря, бедных, так много (только около Астрахани около 10000 семей остались без скота), что обеспечить всех работой невозможно [НА РК. Ф. 36. Д. 154. Л. 33об.].

Наместник, недовольный определением В. Н. Татищева о рыбной ловле, которое разрешало использование малых и сомовых удочек, сетей и неводов до 40-60 сажень, но запрещало ловлю рыбы осетровых пород, написал В. Н. Татищеву: «Когда по Волге земля, вода, трава и лед, все к русским принадлежит, то поданным ея императорского величества нашим калмыкам чрез какой способ исправится я не знаю» [НА РК. Ф. 36. Д. 154. Л. 33об.].

С первых же шагов губернаторства В. Н. Татищев изучал финансовое состояние вверенной ему губернии. Первоначальное рассмотрение этой важнейшей отрасли экономического развития не принесло удовлетворения губернатору. Как он сооб- щал правительству в лице А. И. Остермана, в кабацких и таможенных сборах в деньгах «великий урон учинился», потому что раньше калмыки и татары кочевали по Волге до Самары, и по всем городам - Самаре, Сызрани, Саратове, Дмитриевске - и в лежащих между ними селах «имели великие торги». Вследствие этого кабацкий и таможенный сбор был большой, а после смерти хана Аюки, как начались междоусобицы, большая часть татар откочевала на Кубань. Оставшиеся татары и калмыки в основном держались близ Астрахани и Царицына, а ныне выше последнего не ходят. Поэтому в городах по Волге выше Царицына даже трети против прежнего собрать нельзя [НА РК. Ф. 36. Д. 133. Л. 68].

Если описанное губернатором положение и было таковым, калмыцкому населению от этого было не легче. 2 мая 1744 г. наместник писал В. Н. Татищеву: «Многие люди мне объявляют, что с калмык наших как с ездящих на своих лодках, так с тулупов, с овчин, с мерлушак и с рыбы имание денег и пошлин пред прежним наипаче умножилось, а понеже на пред сего такова обыкновения не бывало, тако ж и ныне в том вновь указа не имеется», а потому просит прекратить подобную практику [НА РК. Ф. 36. Д. 180. Л. 3].

Уже после В. Н. Татищева наместник писал руководителю Калмыцких дел от 1 ноября 1745 г.: «Известно мне, что с имеющихся при Волге владения моего скудных калмык с каждой лодки берут половных денег по три рубли, о чем я и в прошлом году писал. Однако по худым Татищева замыслам оное и поныне брать не запрещено» [НА РК. Ф. 36. Д. 193. Л. 20].

Вопросы обнищания калмыцкого народа, по мнению В. Н. Татищева, имели своё решение не только в рыбной ловле. Проблемы он усматривал, по всей видимости, ещё в религиозных практиках буддизма. Например, он указал в беседе владельцу Бордону ${ }^{1}$, что слишком много денег калмыки тратят на содержание своего духовенства. На возражение Бордона о том, что в иные времена платили и больше, В. Н. Татищев ответил, что при Аюке калмыков было «семьдесят тысяч кибиток, да более тритцети тысяч

${ }^{1}$ Владелец Бордон - зайсанг наместника Дондук-Даши. 
татар», а ныне менее тридцати тысяч, да ещё и «бесскотных» [НА РК. Ф. 36. Д. 177. Л. 328-329].

В беседах с Эби Гелюном, своим калмыцким знакомым, коллежский асессор Ф. Черкассов, который был своеобразным посланником В. Н. Татищева в калмыцких улусах, обратил внимание, что калмыки продают «ясырей» (видимо, пленников-батраков). На это Эби ответил ему, что это происходит из-за обеднения. Очевидно, что в отсутствие скота работники и рабочая сила была не нужна.

Впрочем, калмыцкие владетели, и Эби Гелюн, а затем и зайсанг Шонхолдок, докладывали Ф. Черкассову, что не сами по себе простые калмыки обеднели, а их к этому привели различные поборы и сборы со стороны более богатых и знатных. В то же время, подметил зайсанг Шонхолдок, к Дондук-Даши обращаться смысла нет, так как тот занимается религиозными вопросами [НА РК. Ф. 36. Д. 180. Л. 209].

\section{Заключение}

Петровская эпоха выдвинула из своей среды людей, чьи имена впоследствии навечно были вписаны в историю отечества. С именем В. Н. Татищева связан почти пя-

\section{Источники}

РГАДА - Российский государственный архив древних актов.

НА РК - Национальный архив Республики Калмыкия.

\section{Литература}

Батмаев 2004 - Батмаев M. M. Татищев как руководитель Калмыцких дел // Исторические судьбы России в научном наследии В Н. Татищева: мат-лы Междунар. науч. конф. (г. Астрахань, 14-16 октября 2004 г.). Астрахань: АГУ, 2004. С. 60-69.

Болтин 1794 - Болтин И. Н. Критические примечания генерал-майора Болдина на второй том Истории князя Щербатова. СПб.: Тип. Корп. чужестр. единоверцев, 1794. 479 с.

Болтин 1789 - Болтин И. Н. Ответ генерал-майора Болтина на письмо князя Щербатова, сочинителя Российской истории. СПб.: Тип. Горнаго училища, 1789. 181 с.

Дейч 1962 - Дейч Г. М. В. В. Татищев: историк и государственный деятель. 1686-1750. Свердловск: Кн. изд-во, 1962. 76 с. тилетний период развития Астраханской губернии.

Занимая должности губернатора Астраханской губернии с 1741 по 1745 гг. и главы Калмыцкой комиссии при Коллегии иностранных дел, В. Н. Татищев особое внимание уделял социально-экономическому развитию края, в том числе и вопросам обустройства калмыков. Выполняя задачи по примирению калмыцкой знати, В. Н. Татищев интересовался также нуждами простых калмыков. Создаётся впечатление, что бедственное положение простых калмыков, которые зачастую оставались без средств к существованию, действительно волновало его, пусть и по сугубо военным и имперским мотивам. Так, по его мнению, теряя скот и прежде всего коней, калмыки не смогли бы приносить пользу Российской империи. Хотя он так и не смог на практике облегчить жизнь простых калмыков, столкнувшись с сопротивлением и интригами калмыцких владетелей, а также в силу несовершенства государственного управления в калмыцких улусах, следует отметить, что сочувственное отношение к положению народных масс было редким явлением среди чиновников того времени.

\section{Sources}

Russian State Archive of Ancient Acts. National Archive of the Republic of Kalmykia.

Интервью 2001 - Интервью с губернатором Астраханской области А. П. Гужвиным // Волга. Астрахань. 2001. 21 декабря. С. 2.

Исторические судьбы России 2004 - Исторические судьбы России в научном наследии В. Н. Татищева. Материалы Международной научной конференции (г. Астрахань, 14-16 октября 2004 г.). Астрахань: АГУ, 2004. $167 \mathrm{c}$.

Качин 2014 - Качин Н. А. В. Н. Татищев прообраз первого российского историка // Вестник Томского государственного университета. История. 2014. № 1 (27). С. 98-102.

Кузьмин 1987 - Кузьмин А. Г. Татищев. М.: Молодая гвардия, 1987. 368 с.

Пальмов 1925 - Пальмов Н. Н. К астраханскому периоду жизни В. Н. Татищева // Известия РАН. 1925. № 6/8. С. 207-224. 
Попов 1861 - Попов Н. В. Н. Татищев и его время. М.: Тип. В. Грачева и К., 1861. 804 с.

Свердлов 2009 - Свердлов М. Б. Василий Никитич Татищев - автор и редактор «Истории Российской». СПб.: Европейский Дом, 2009. $341 \mathrm{c.}$

Щербатов 1789 - Щербатов М. М. Письмо князя Щербатова, сочинителя Российской истории, к одному его приятелю в оправдание на не-

\section{References}

Batmaev M. M. Tatishchev as head of Kalmyk Affairs Commission. In: Ishin V. V., Toropitsyn I. V. (eds.) Historical Destinies of Russia in Vasily Tatishchev's Scholarly Heritage. Conference proceedings. Astrakhan: Astrakhan State University, 2004. Pp. 60-69. (In Russ.)

Boltin I. N. Major General Boltin's Reply to the Letter of Prince Shcherbatov, Author of The History of Russia. St. Petersburg: Mining College, 1789. 181 p. (In Russ.)

Boltin I. N. The History of Russia by Prince Shcherbatov: Censorious Remarks to Volume 2. St. Petersburg: Korpus Chuzhestrannykh Edinovertsev, 1794. 479 p. (In Russ.)

Deutsch G. M. Vasily B. Tatishchev: Historian and Statesman, 1686-1750. Sverdlovsk: Sverdlovsk Book Publ., 1962. 76 p. (In Russ.)

Interview with Governor A. P. Guzhvin. Volga. Astrakhan'. 2001, December 21. P. 2. (In Russ.)

Ishin V. V., Toropitsyn I. V. (eds.) Historical Destinies of Russia in Vasily Tatishchev's Scholarly Heritage. Conference proceedings. Astrakhan: Astrakhan State University, 2004. 167 p. (In Russ.) которые сокрытия и явные охуления, учиненные его Истории от господина генерал-майора Болтина, творца примечаний на Историю древния и нынешния России г. Леклерка. М.: Унив. тип., у Н. Новикова, 1789. 149 с.

Щербатов 1792 - Щербатов М. М. Примечание на ответ господина генерал-майора Болтина на письмо Щербатова. М.: Унив. тип., у В. Окорокова, 1792. 624 с.

Kachin N. A. V. N. Tatishchev - the prototype of the first Russian historian. Tomsk State University Journal of History. 2014. No. 1 (27). Pp. 98-102. (In Russ.)

Kuzmin A. G. Tatishchev. Moscow: Molodaya Gvardiya, 1987. 368 p. (In Russ.)

Palmov N. N. Astrakhan period of Vasily Tatishchev's life revisited. Izvestiya RAN. 1925. No. 6/8. Pp. 207-224. (In Russ.)

Popov N. Vasily Tatishchev and His Era. Moscow: V. Grachev \& Co., 1861. 804 p. (In Russ.)

Shcherbatov M. M. Major General Boltin's Reply to the Letter of Prince Shcherbatov: Author's Remarks. Moscow: V. Okorokov, 1792. 624 p. (In Russ.)

Shcherbatov M. M. Prince Shcherbatov's Letter to a Friend of His Aiming to Explain Some Concealments and Calumnies against The History of Russia from Major General Boltin, Author of Censorious Remarks. Moscow: N. Novikov, 1789. 149 p. (In Russ.)

Sverdlov M. B. The History of Russia: Vasily Nikitich Tatishchev as Author and Editor. St. Petersburg: Evropeyskiy Dom, 2009. 341 p. (In Russ.) 